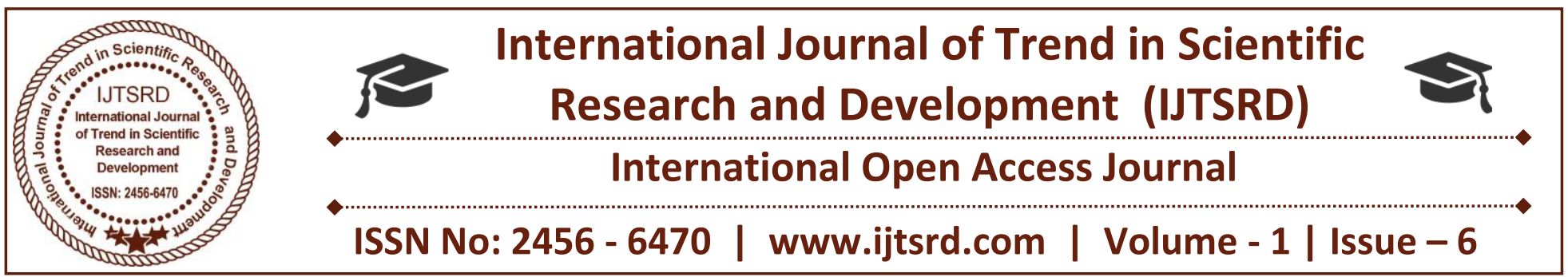

\title{
Gender Difference Between Youth Problems
}

\author{
Dr.Ramesh D. Waghmare \\ Godawari College Ambad, Jalna, \\ Maharastra, India
}

\section{ABSTRACT}

The study was undertaken to study the youth Problems of male and female college students of district Jalna (M.S.). The sample of the study consisted 400college students (200 male students and 200 female students). Randomly secreted from Difference College of Jalna District(M.S.). Youth Problem Inventory by Dr. M. Verma(2004) was used data collection. The data collected was statistically treated by using mean, SD and one way ANOVA. The findings of the study revealed that Girls have significantly high Family Problem than Boy. Girls have significantly high School Problem than Boy. There is no significant difference between boys and girls graduate student dimension on Social problem. There is no significant difference between boys and girls graduate student dimension on Personal Problem. Girls have significantly high Youth Problem than Boy

Keywords: Gender, Youth Problem, Family Problem, School Problem, Social problem, Personal Problem

\section{INTRODUCTION}

The word youth or adolescent can be interchanged. The synonyms of youth are teenager, youngster, adolescent, stripling etc. Mudasir, Shazia Majeed (2000), "Youth means quality or condition of being young, immature, or inexperienced; the period between childhood and maturity especially adolescence and early adulthood; the freshness, vigor or vitality characteristics of young people; any period of early development; a young person, especially a young man or boy".

Youth are the hope of the future of the world or in other words the future of the world lies in the hands of the youth. It is they who build up the nations. Youth are the resources of country and it their empowerment is the empowerment of a nation. The present generations have their hope in the youth. They are productive and active people who are capable of large undertakings. In the midst of their strong and stubborn nature we realize the fact that there are several problems among the present day youth. These problems are most often psychological and are developed during their stages of development. There is no other way but to recognize, identify and find out remedies to such problems of the youth. The science of psychology and the Psycho analysis has been contributed much to the youth related problems and solutions. Youth psychology is a branch of psychology that develops very fast. Let the youth of the world merit from the psychological innovations of psyche of the youth.

\section{Review of Literature:}

Srishti Singh, (2016) indicated that no significant gender differences lie in family problems, college problems, social problems or personal problems of college students. Anjana s. Chauhan and Gandhrva R. Joshi, (2014), indicated that male and female college students do not differ significantly to their youth Problems. However Educational streams affect on Youth Problems at .05 level and insignificant interaction effect found between gender and educational streams. From the obtained result it is clear that type of family ignificantly differ in Youth Problems of the students. Whereas, there is no 
significant difference found between type of residence and Youth Problems of students as well as Socioeconomic status and Youth Problems of College students. Sharma, Sonia (1992) found that adolescents have to face maximum number of problems, whereas urban boys have more family problems. Sangeeta, Sharma, A. \& Kumar, J. (November 2013) found that Significant difference was detected between mean scores on 'Family Problems' in adolescent girls, 'Social Problems' and Personal Problems' were significantly high in girls. And Social Problems' and 'Personal Problems' were found to be significantly higher in adolescent girls. Firdous A. Var, et al. (2011) indicated that significant difference was found between rural and urban adolescents in family, school, social and personal problems. Male and female groups differed significantly only in personal problems. Significant difference was found among all the three levels of self esteem and their personal and family problems. Overall findings suggest those rural adolescents suffer more problems than urban adolescents and thus highlight. The need of community based mental health care. Satinder Dhillon,(2015) this study indicated that male and female students have the same means on their personal problems. The mean scores of female students in case of family, socio-emotional and educational problems were more than their counterparts but this difference is statistically not significant. Thus it was concluded that there is no significant difference in the mean scores of youth problems of male and female students. Irshad Ali Dar and Latief Ahmad Tali, (2014) this study found that the adolescent boys and girls of Kashmir have high adjustment problems in various areas like family, school, social and on a personal front. It was found that the adolescent boys and girls of Kashmir do not differ significantly with each other in adjustment problems.

\section{Statement of the Problem}

To Study the Youth Problems among Boys and Girls college going Students.

\section{Objectives}

The following are main objectives of the present study.

To examine the youth problem among boys and girls college going Students.

\section{Hypotheses:-}

"There is no significant difference between boys and Girls College going Students dimension on youth problem. (Family, school social and personal)."

\section{Methods:-}

\section{Sample:-}

For the present study 400 samples was selected from Jalna Dist. in Maharashrta. The effective sample consisted of 400 subjects among them 200 subjects Boys Urban students 100 and rural students 100 and 200 subjects girls (Urban students 100 and rural students 100. The age range of subjects was 18-21 years $($ Mean $=20.26, \quad \mathrm{SD}=3.25)$ Non-Probability purposive sampling was used.

\section{Research Design:-}

Simple research design used in the present study

\section{Variables of the Study}

\begin{tabular}{|c|c|c|c|}
\hline Variable & $\begin{array}{l}\text { Type of } \\
\text { variable }\end{array}$ & $\begin{array}{l}\text { Sub. } \\
\text { variable }\end{array}$ & $\begin{array}{l}\text { Name of } \\
\text { variable }\end{array}$ \\
\hline $\begin{array}{l}\text { Area of } \\
\text { Residence }\end{array}$ & $\begin{array}{l}\text { Independ } \\
\text { ent }\end{array}$ & 2 & $\begin{array}{l}\text { 1) Urban } \\
\text { 2) Rural }\end{array}$ \\
\hline $\begin{array}{l}\text { Youth } \\
\text { Problems }\end{array}$ & $\begin{array}{l}\text { Depende } \\
\mathrm{nt}\end{array}$ & 04 & $\begin{array}{l}\text { 1) Family } \\
\text { 2) school } \\
\text { 3) Social } \\
\text { 4) Personal } \\
\text { 5) Youth } \\
\text { problem }\end{array}$ \\
\hline
\end{tabular}

\section{Research Tools:-}

\section{Youth Problem Inventory (2004)}

This scale was developed by Dr. M. Verma (2004), these inventory 80 items. It is a self administering inventory for the Adolescence students of age to locate the problems in four areas - Family, School/College, Social \& Personal and other subareas under each main area. A high score in an area indicates high problem in that particular area. Reliability of the Inventory is found to be .80 , whereas validity is in the range of .68 - .75. 


\section{Procedures of data collection:-}

For the present study 400 sample was used and two instruments were administered individuals as well as a small group will be adopted. The subjects were called in a small group of 21-25 subjects and there seating arrangements, was made in a classroom. Following the instructions and procedure suggested by the author of the test. Tests were administered and a field copy of each test was collected. Following the same procedure the whole data was collected.

\section{Data Analysis}

The data were analyzed as follows.

The Mean and SD with graphical representation for Area of Residence (Urban and Rural College Students) on youth Problem was analyzed. A simple design was selected to adequate of statistical analysis of ANOVA in order to examine the roll of main as well as subsequently on students Youth Problem.

\section{Results and Discussion}

The analysis of data interpretation and discussion of the results are presented below.

\section{Mean, SD and F Value of Gender on Family Problem}

Table No. 01.

\begin{tabular}{|l|l|l|l|l|l|l|}
\hline & Mean & SD & N & DF & $\begin{array}{l}\text { F } \\
\text { Value }\end{array}$ & Sign. \\
\hline $\begin{array}{l}\text { Boy } \\
\text { Girl }\end{array}$ & 77.89 & 17.30 & 200 & 198 & 9.21 & 0.01 \\
\hline
\end{tabular}

\section{Figure No.01.}

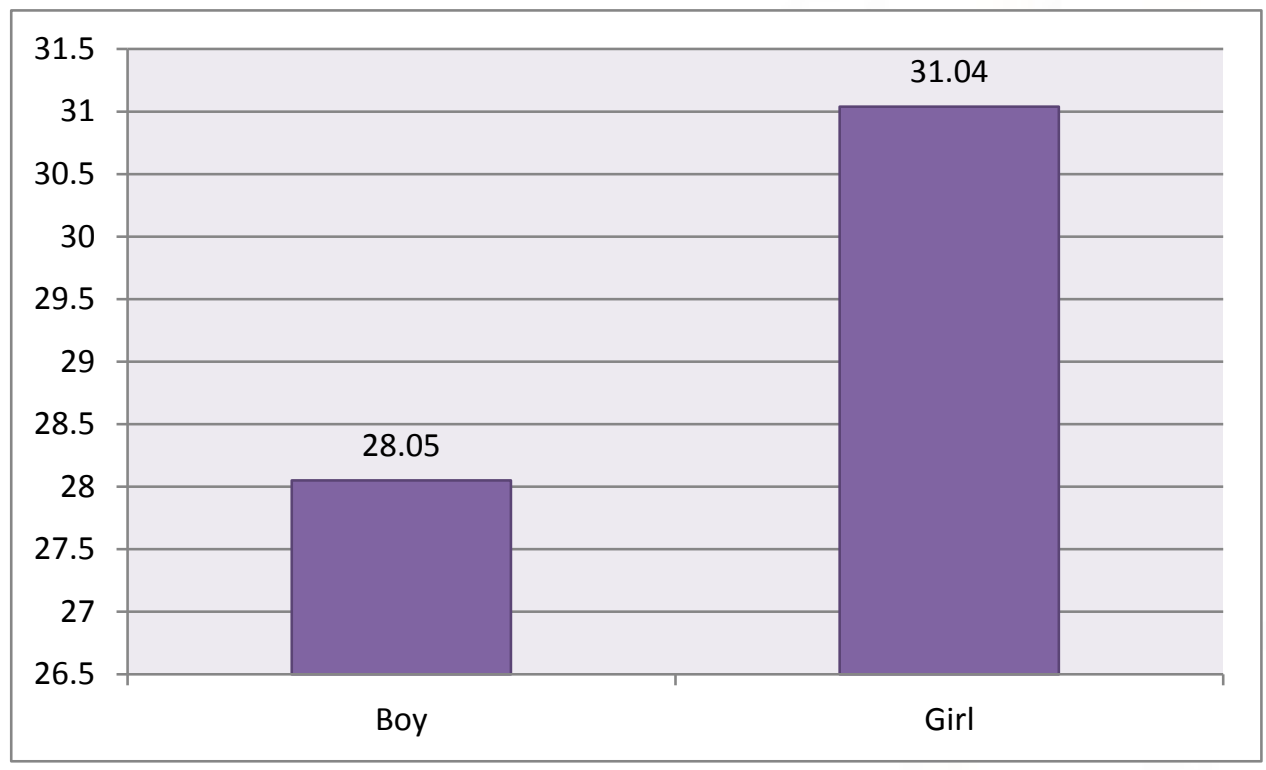

Observation of the table No.01 and Figure No. 01 Indicated that the mean value of two classified group seems to differ from each other on Family Problem. The mean and SD value obtained by Boy (A1) is 28.05, SD = 7.13 and second mean of Girls (A2) is 31.04, $\mathrm{SD}=8.83$ dimension on Family and F value is 14.28 and two mean is highly significant at 0.01 level and 0.05 level and both levels is significant as well as null research hypothesis is rejected (There is no significant difference between boys and girls graduate student dimension with youth problem on Family. and it means that Girls have significantly high Family Problem than Boy.

\section{Mean, SD and F Value of Gender on School Problem}

Table No. 02.

\begin{tabular}{|l|l|l|l|l|l|l|}
\hline & Mean & SD & N & DF & $\begin{array}{l}\text { F } \\
\text { Value }\end{array}$ & Sign. \\
\hline $\begin{array}{l}\text { Boy } \\
\text { Girl }\end{array}$ & 20.26 & 6.57 & 200 & 198 & 12.91 & 0.01 \\
\hline
\end{tabular}


Figure No. 02.

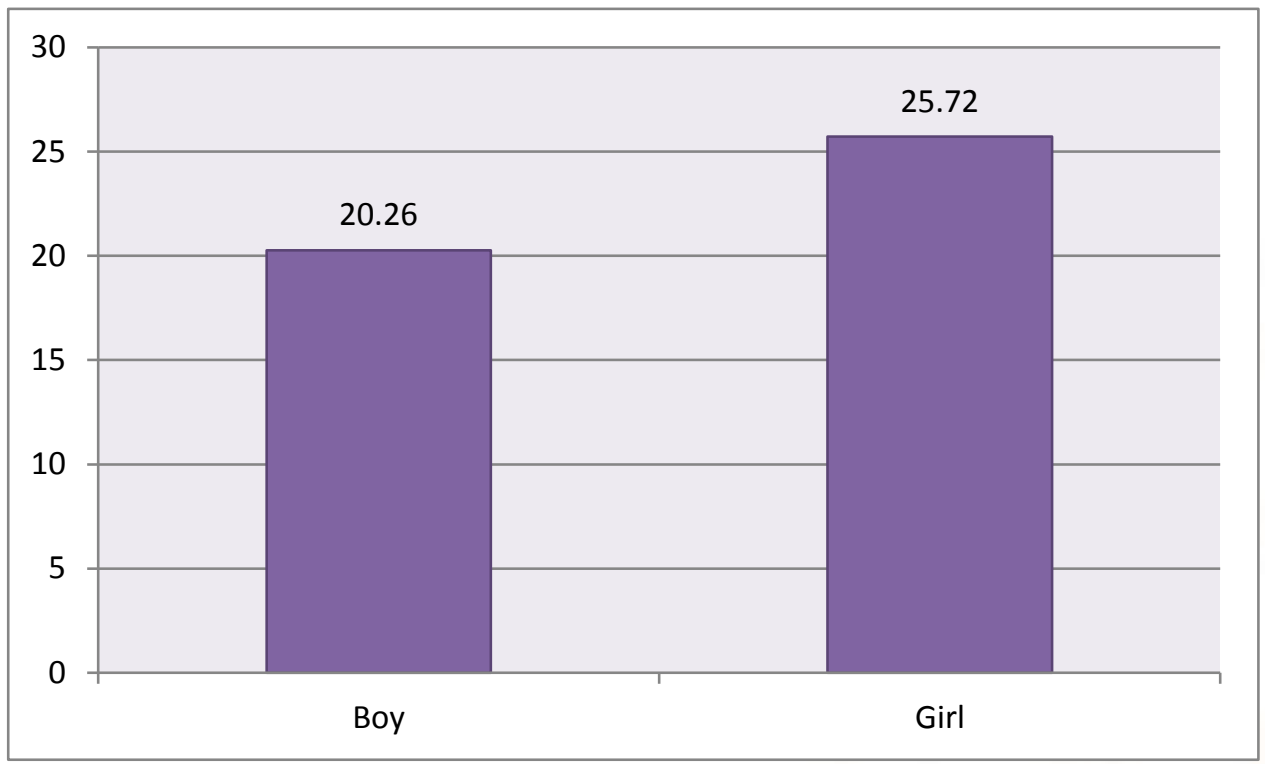

Observation of the table No.02and Figure No. 2 indicated that the mean value of two classified group seems to differ from each other on School Problem. The mean and SD value obtained by Boy (A1) is 20.26, SD $=6.57$ and second mean of Girls (A2) is 25.72, $\mathrm{SD}=7.12$ dimension on School and $\mathrm{F}$ value is 12.91 and two mean is highly significant at 0.01 level and 0.05 level and both levels is significant as well as null research hypothesis is rejected (There is no significant difference between boys and girls graduate student dimension with youth problem on School. and Mean, SD and $F$ Value of Gender on Social Problem

Table No. 03.

\begin{tabular}{|l|l|l|l|l|l|l|}
\hline & Mean & SD & N & DF & F & Sign. \\
Value & \\
\hline $\begin{array}{l}\text { Boy } \\
\text { Girl }\end{array}$ & 5.14 & 2.11 & 200 & 198 & 0.051 & NS \\
\hline
\end{tabular}
it means that Girls have significantly high School Problem than Boy.

Figure No.03.

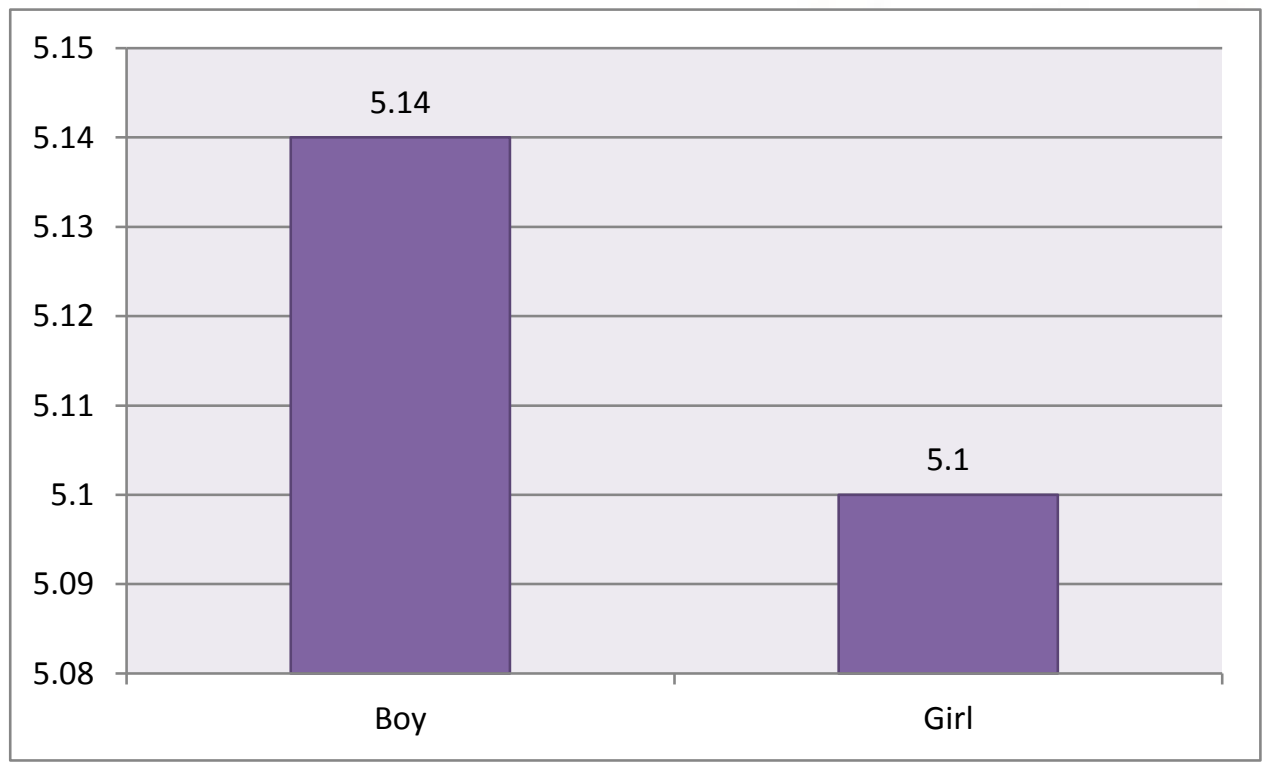

Observation of the table No.03and Figure No. $3 \mathrm{SD}=2.11$ and second mean of Girls (A2) is 5.10, SD indicated that the mean value of two classified group $=2.11$ dimension on Social Problem and $F$ value is seems to differ from each other on Social Problem. 0.051 and two mean not significant at 0.01 level and The mean and SD value obtained by Boy (A1) is 5.14, 0.05 level and both levels is significant as well as null 
research hypothesis is accepted its mean that (and it means that There is no significant difference between boys and girls graduate student dimension on Social problem.
Table No. 04.

\begin{tabular}{|l|l|l|l|l|l|l|}
\hline & Mean & SD & N & DF & $\begin{array}{l}\text { F } \\
\text { Value }\end{array}$ & Sign. \\
\hline Boy & 24.44 & 8.16 & 200 & 198 & 0.098 & NS \\
Girl & 24.71 & 9.57 & 200 & & & \\
\hline
\end{tabular}

Mean, SD and F Value of Gender on Personal Problem

Figure No.04.

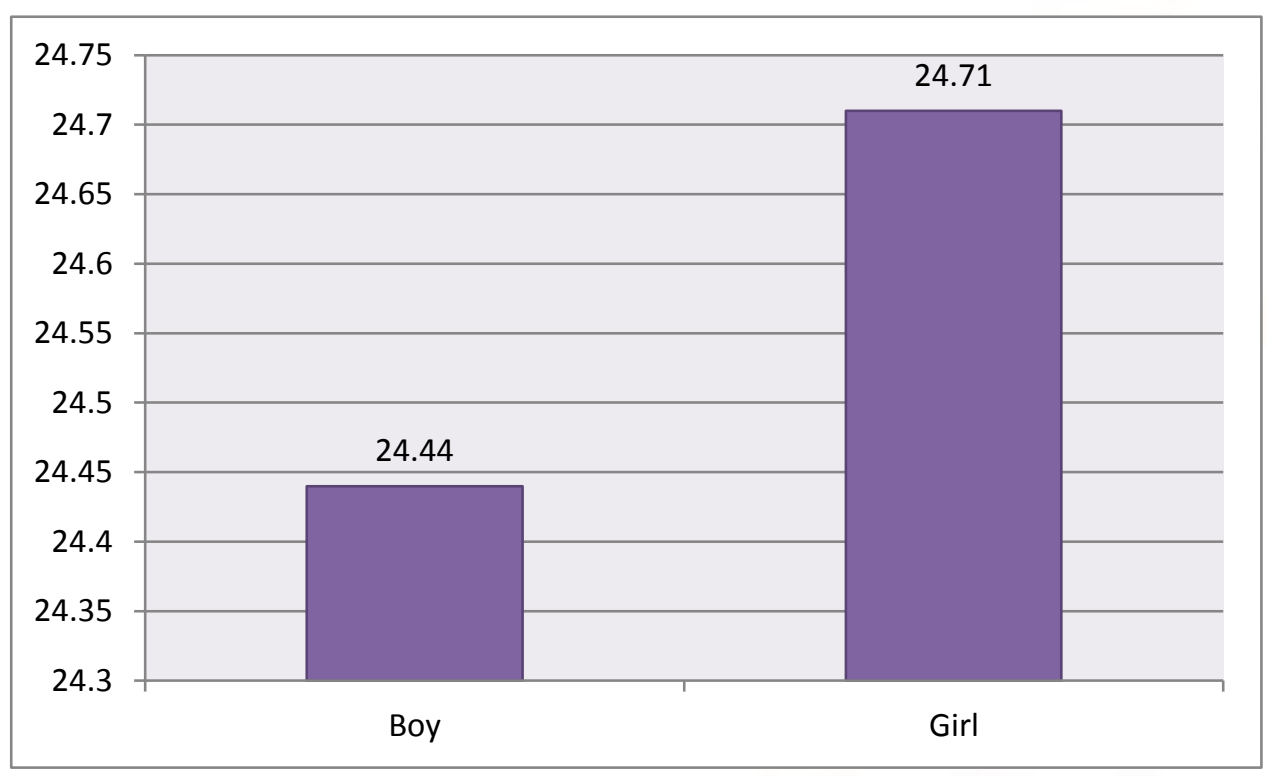

Observation of the table No.04and Figure No. 4 indicated that the mean value of two classified group seems to differ from each other on Personal Problem. The mean and SD value obtained by

Boy students (A1) is 24.44, SD = 8.16 and second mean of Girls students (A2) is 24.71, SD $=9.57$ dimension on Personal Problem and F value is 0.098 and two mean not significant at 0.01 level and 0.05 level and both levels is significant as well as null research hypothesis is accepted its mean that (and it means that There is no significant difference between boys and girls graduate student dimension on Personal Problem.
Mean, SD and F Value of Gender on Youth Problem

Table No. 4.1.2.05

\begin{tabular}{|l|l|l|l|l|l|l|}
\hline & Mean & SD & N & DF & $\begin{array}{l}\text { F } \\
\text { Value }\end{array}$ & Sign. \\
\hline Boy & 77.89 & 17.30 & 200 & 198 & 9.21 & 0.01 \\
Girl & 83.58 & 20.38 & 200 & & & \\
\hline
\end{tabular}


Figure No.05.

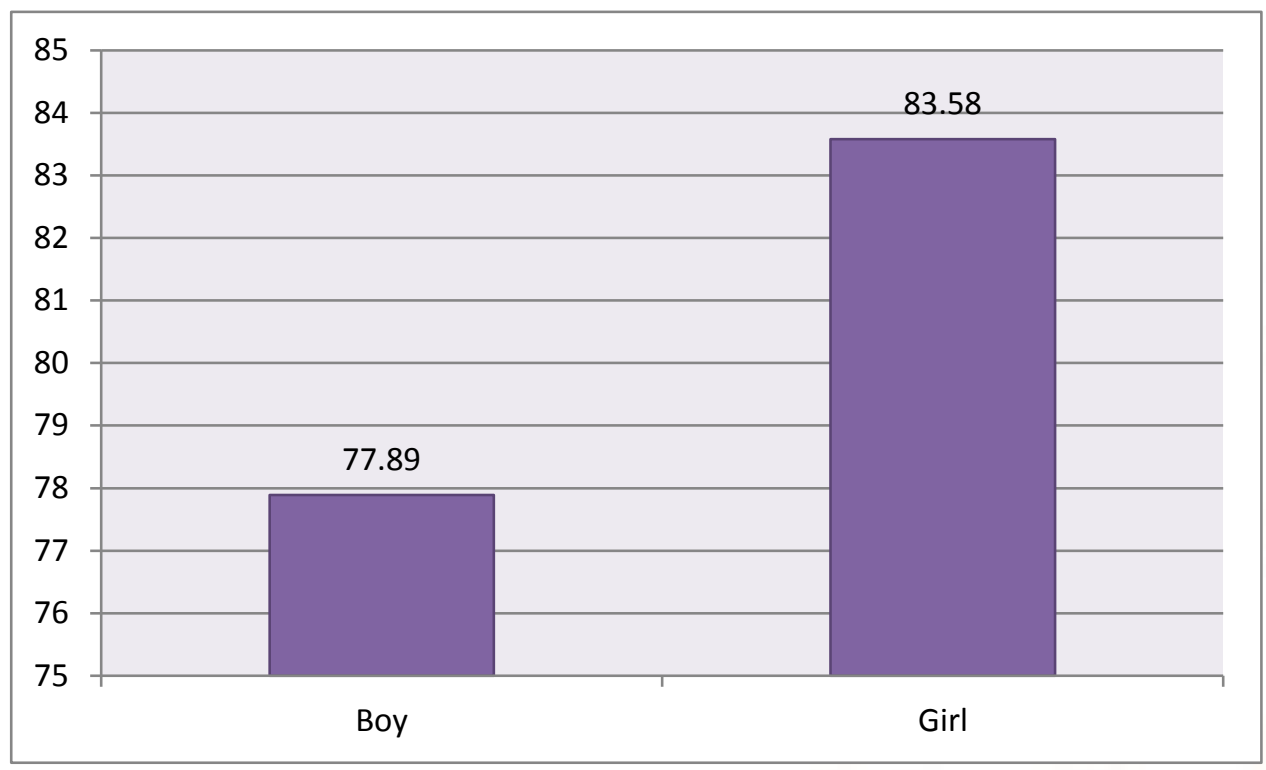

Observation of the table No.05and Figure No. 05 indicated that the mean value of two classified group seems to differ from each other on youth Problem. The mean and SD value obtained by Boy (A1) is $77.89, \mathrm{SD}=17.30$ and second mean of Girls (A2) is 83.58, SD $=20.38$ dimension on Youth Problem and $\mathrm{F}$ value is 9.21 and two mean is highly significant at 0.01 level and 0.05 level and both levels is significant as well as null research hypothesis is rejected (There is no significant difference between boys and girls graduate student dimension with youth problem. and it means that Girls have significantly high Youth Problem than Boy.

\section{Delimitations of the study}

1) The finding of the study is based on very sample.

2) The sample was restricted to Jalna Dist. in Maharashrta.

3) The study was restricted to only B.A. arts college students (arts facility) only.

4) The study was restricted students are only 18-21 years only.

\section{Conclusions}

1) Girls have significantly high Family Problem than Boy.

2) Girls have significantly high School Problem than Boy.

3) There is no significant difference between boys and girls graduate student dimension on Social problem.
4) There is no significant difference between boys and girls graduate student dimension on Personal Problem.

5) Girls have significantly high Youth Problem than Boy.

\section{REFERENCES}

1) Anjana s. Chauhan and Gandhrva R. Joshi, (April 2014), Problems of Youth- A study of College Students in context to their Gender and Educational stream, Asian Resonance; 3, (2), 175177.

2) Chaudhari, R., 2012, A study of attitudes of B.Ed. trainees towards modernization. International Indexed \& Refered Journal, Vol. 1 , Issue 1.

3) Firdous A. Var, Mohd. Altaf Pau,Pradeep Kumar, Showkat A. Shah,( OCTOBER 2011) Self-esteem and Psychosocial problems among Kashmiri Youth; Delhi Psychiatry Journal; 14:(2) ,307-313.

4) Ghanshyam Thakur and Dinesh kumar Lahari, (Apirl 2016), A COMPARATIVE STUDY TO MAJOR YOUTH PROBLEM AMONG COLLEGE STUDENT ON BASIC OF LOCALITY, International Journal of Humanities, Arts, Medicine and Sciences (BEST: IJHAMS) 4, (4), 47-50.

5) Irshad Ali Dar and Latief Ahmad Tali, (2014) Adjustment Problems among Kashmiri Adolescents; International Journal of English Language, Literature and Humanities, 1, (5), 99107.

6) Ishfaq ahmad and Ishrat Jan( Jan.2016) Modernization and Social Awareness among Male and Female College Students in District Shopian, 
J \& K. International journal of Multidisplinary Research - Vol. II, Issue 1,901-906.

7) Sangeeta, Sharma, A. \& Kumar, J. (November 2013) A Study of Adolescent's Problems in Relation to Academic Achievement of Girls at Senior Secondary Level, Educationia Confab; 2, ( 11), 55-62.

8) Satinder Dhillon,(2015) A Study of Youth Problems In Relation To Modernization; Educationia Confab, Vol. 4, No. 4,1-8.

9) Sharma, Sonia (1992). "A comparative study of problems of adolescents from rural and urban background M.Ed. dissertation Punjab University, Chandigarh.

10) Srishti Singh, (2016) Problems of youth: A study of college students in context to their gender; International Journal of Home Science; 2(1): 1821.

11) Waghmare, R.D., (2016), A Study of Psychological Well Being Among Male and Female College Students, International Journal of Indian Psychology, Volume 3, Issue 3, No. 7,2631. 